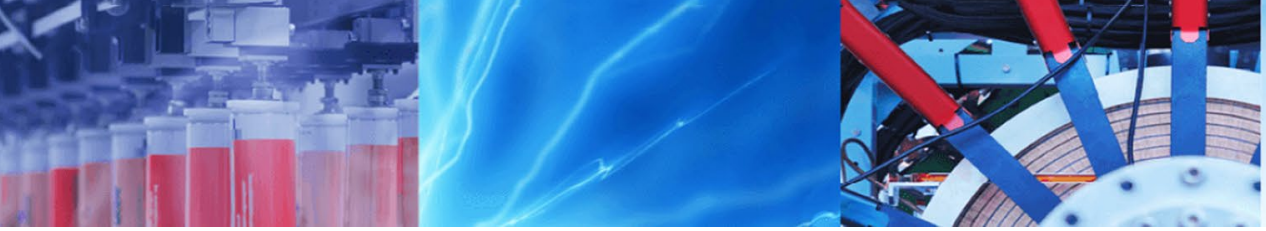

\title{
Correction
}

\section{Correction to: Earthquake-induced clastic dyke and fluid inflow at the Miguel Burnier manganese-ore deposit, Quadrilátero Ferrífero of Minas Gerais, Brazil}

\author{
Tiago Henrique DeFerreira ${ }^{1,2}$ (D) Alexandre Raphael Cabral ${ }^{1,3} \cdot$ Francisco Javier Rios $^{1}$
}

Published online: 12 April 2021

(c) The Author(s) 2021 OPEN

\section{Correction to: SN Applied Sciences (2021) 3:342 https://doi.org/10.1007/s42452-021-04297-x}

In the initial online publication, there were minor errors in Table 1, Figs. 3 and 5 and also several cosmetic grammatical and spelling errors. The original article has been corrected.

Open Access This article is licensed under a Creative Commons Attribution 4.0 International License, which permits use, sharing, adaptation, distribution and reproduction in any medium or format, as long as you give appropriate credit to the original author(s) and the source, provide a link to the Creative Commons licence, and indicate if changes were made. The images or other third party material in this article are included in the article's Creative Commons licence, unless indicated otherwise in a credit line to the material. If material is not included in the article's Creative Commons licence and your intended use is not permitted by statutory regulation or exceeds the permitted use, you will need to obtain permission directly from the copyright holder. To view a copy of this licence, visit http://creativecommons. org/licenses/by/4.0/.

Publisher's Note Springer Nature remains neutral with regard to jurisdictional claims in published maps and institutional affiliations.

The original article can be found online at https://doi.org/10.1007/s42452-021-04297-x.

$\triangle$ Tiago Henrique DeFerreira, tiagohdeferreira@gmail.com $\mid{ }^{1}$ Centro de Desenvolvimento da Tecnologia Nuclear, Universidade Federal de Minas Gerais (UFMG), Av. Presidente Antônio Carlos, 6627, Campus Pampulha, Belo Horizonte, MG 31270-901, Brazil. ${ }^{2}$ Graduate Programme of Centro de Desenvolvimento da Tecnologia Nuclear (CDTN/CNEN), Belo Horizonte, Brazil. ${ }^{3}$ Centro de Pesquisas Professor Manoel Teixeira da Costa (CPMTC), Instituto de Geociências, UFMG, Belo Horizonte, MG, Brazil. 